\title{
EVIDENCE OF RECENT POPULATION INCREASES IN COMMON EIDERS BREEDING IN LABRADOR
}

KEITH CHAULK, ${ }^{1}$ Labrador Inuit Association, Goose Bay, Newfoundland and Labrador, A0P 1C0, Canada GREGORY J. ROBERTSON, Canadian Wildlife Service, 6 Bruce Street, Mount Pearl, Newfoundland and Labrador, A1N 4T3, Canada BRIAN T. COLLINS, Canadian Wildlife Service, National Wildlife Research Centre, Raven Road, Carleton University, Ottawa, Ontario, $\mathrm{K} 1 \mathrm{~A}$ OH3, Canada

WILLIAM A. MONTEVECCHI, Department of Psychology, Memorial University of Newfoundland, St. John's, Newfoundland and Labrador, A1B 3X9, Canada

BRUCE TURNER, Canadian Wildlife Service, 6 Bruce Street, Mount Pearl, Newfoundland and Labrador, A1N 4T3, Canada

JOURNAL OF WILDLIFE MANAGEMENT 69(2):805-809; 2005

Key words: common eider, Labrador, nest counts, population trend, Program ESTEQNINDEX, Somateria mollissima.

Populations of several sea ducks are declining across their North American ranges (Sea Duck Joint Venture Management Board 2001 ), including populations of all 4 eider species (Somateria spp. and Polysticta steller, Kertell 1991, Stehn et al. 1993, Gratto-Trevor et al. 1998). Declines in common eider populations have been documented in Greenland, Hudson Bay, and Alaska (Robertson and Gilchrist 1998, Sudyam et al. 2000, Merkel 2004). Reasons behind these population decreases vary, and many are unclear. Factors identified as causing these declines include human disturbance, overharvesting, and climatic events (Robertson and Gilchrist 1998, Suydam et al. 2000, Merkel 2004). However, not all common eider populations in the north are decreasing; Christensen and Falk (2000) recently found evidence of population increase in an eider population in Northwest Greenland, while others have documented increases in Hudson Strait (Hipfner et al. 2001, Falardeau et al. 2003).

Labrador has breeding populations of the northern common eider ( $S$. m. borealis), the American common eider (S. m. dresseri) and intergrades of the 2 subspecies (Mendall 1986). Mendall (1980) documented this zone of overlap, but the geographic extent and consequences for population structure and recruitment have not been fully explored. Most information related to eider breeding ecology in Labrador is outdated (i.e., population trend) or unknown (i.e., migration routes and wintering locations). In terms of population affinities, eiders breeding in Labrador are thought to over winter in Atlantic Canada and the Northeastern United States (Palmer 1976, Goudie et al. 2000).

\footnotetext{
${ }^{1}$ E-mail: kchaulk@nunatsiavut.com
}

In 1998, the Canadian Wildlife Service (CWS) in conjunction with the Labrador Inuit Association (LIA), initiated surveys on the Labrador coast to collect information to estimate breeding eider population trends. These surveys were initiated in anticipation of the finalization of the LIA land claims, subsequent establishment of the Nunatsiavut land claim area and creation of natural resource co-management boards. Surveys covered approximately $750 \mathrm{~km}$ of the Labrador coast and were repeated annually from 1998 to 2003, but due to logistical reasons, not all islands were surveyed every year. We report the findings of these monitoring efforts and compare them with results from other studies.

\section{Study Area}

We surveyed archipelagos near Nain and Hopedale from 1998 to 2003; St. Peter's Bay was surveyed in 1999, 2001 , and 2002 (Chaffey 2003); and Rigolet was surveyed from 2000 to 2003. The Nain study area was approximately $2,237 \mathrm{~km}^{2}$ and contained 811 islands ranging in size from 0.01 to 44,800 ha. The Hopedale study area was approximately 959 $\mathrm{km}^{2}$ and contained 838 islands ranging in size from 0.01 to 3,875 ha. The Rigolet study area was approximately $3,172 \mathrm{~km}^{2}$ and contained 348 islands ranging in size from 0.02 to 5,204 ha. The St. Peter's Bay study area was approximately $14 \mathrm{~km}^{2}$ and contained 20 islands ranging in size from 0.03 to 23.43 ha.

All regions shared similar environmental characteristics such as a northern maritime climate, vegetation composed primarily of mosses, lichens, forbs, grasses, and sedges. The archipelagos of Nain, Hopedale, and Rigolet were typically comprised of barren islands with sparse vegetation and very limited nesting cover. Islands in St. Peter's Bay had more ground vegetation and woody cover, such as stunted black spruce (Picea mariana). All 4 archipelagos 
Table 1. Survey dates by year and archipelago for nesting common eiders on the coast of Labrador, Canada, 1998-2003.

\begin{tabular}{ccccc}
\hline Year & Nain & Hopedale & Rigolet & St. Peter's Bay \\
\hline 1998 & 6-10 Jul & 30 Jun-4 Jul & & \\
1999 & 13-15 Jul & 4-12 Jul & & 22-23 Jun \\
2000 & 3-9 Jul & 28-30 Jun & 20-26 Jun & \\
2001 & 5-19 Jul & 4-17 Jul & 18-27 Jun & 11 Jun \\
2002 & 13-22 Jul & 3-17 Jul & 17-22 Jun & 5-9 Jun \\
2003 & 11-13 Jul & 3-7 Jul & 14-20 Jun & \\
\hline
\end{tabular}

were classified as coastal barrens (Lopoukhine et al. 1978) and were considered to have a high-boreal ecoclimate (Meades 1990) and a low arctic oceanographic regime (Nettleship and Evans 1985).

\section{Methods}

In all areas, we selected islands based on random or haphazard sampling (Chaulk et al. 2005). We limited our searches to islands that were estimated to be smaller than $30 \mathrm{ha}$. Since large islands require significant effort to search, we focused on smaller islands that could be easily censused by small field crews over restricted periods. We conducted ground surveys using standard search methods employed by the Canadian Wildlife Service (Nettleship 1976) and other researchers (Falardeau et al. 2003, Merkel 2004); these consisted of 2-4 people systematically walking over the islands searching for signs of eider nesting. Islands in the 4 northern archipelagos had limited cover, and hens and unattended nests were easily detected. In several instances we stopped island searches because of weather or logistical considerations. If searches were halted, the island was classed as partially searched and was not used in trend analysis. We searched islands once per year. We initiated surveys in the south, and the survey crews moved north as the summer progressed; surveys were timed to occur during mid-incubation but actual timing varied slightly by archipelago and year (Table 1 ).

Sample sizes for the annual monitoring effort were estimated based on data collected in Nain

Table 2. Sampling effort from 1998 to 2003 and summary of islands and their sizes for each archipelago surveyed on the Labrador coast from 1998 to 2003.

\begin{tabular}{lccc}
\hline & $\begin{array}{c}\text { No. of islands } \\
<30 \text { ha searched }\end{array}$ & $\begin{array}{c}\text { No. of islands } \\
\text { No. of } \\
\text { in archipelago }\end{array}$ & $\begin{array}{c}<30 \text { ha in } \\
\text { archipelago }\end{array}$ \\
Archipelago & $1998-2003$ & 811 & 740 \\
Nain & 36 & 838 & 789 \\
Hopedale & 49 & 348 & 326 \\
Rigolet & 22 & 20 & 20 \\
St. Peter's Bay & 10 & 1,995 & 1,875 \\
Total & 117 & & \\
\hline
\end{tabular}

and Hopedale during 1998 using the software program MONITOR and its exponential model (Users Manual, J.P Gibbs). We input island nest counts and an archipelago level standard deviation and varied the number of islands, surveys, and survey occasions to produce a matrix of possible sampling schemes that would generate statistical power $>0.80$ with alpha $=0.10$. Archipelago level standard deviation was calculated using the bootstrap method (Sokal and Rohlf 1995). The sampling scheme matrix was used to guide sampling effort in post-1 999 sampling years.

For trend estimation, we used nest counts from islands that were completely searched and ran the analysis using islands searched a minimum of 2, 3, and 4 years. Trends were estimated using the program ESTEQNINDEX, which fit the mean island nest count to a 2-way model with terms for year and island. Maximum likelihood estimates of year effects were calculated assuming observed counts had a Poisson distribution. An exponential trend was then fit through the year effects, and the jackknife estimate of the standard error was computed. This procedure was originally developed for analysis of the Breeding Bird Surveys and supports trend analysis with missing data (Collins 2003).

\section{Results}

From 1998 to 2003, 117 islands (Table 2) were completely surveyed a total of 479 times in 4 archipelagos (Nain, Hopedale, Rigolet, St. Peter's Bay), and over this period, we counted 13,185 eider nests. Average nest counts per island increased from a low of 3.3 in Hopedale in 1998 to over 10.7 nests/island in 2003, while in Nain, average nest counts increased from a low of 14.5 in 1998 to over 46.3 in 2003 (Table 3). Our most comprehensive study year was 2002 , in which we sampled 109 islands in 4 archipelagos and counted 3,239 nests. These 109 islands represent about $5.8 \%$ of all islands on the Labrador coast $<30$ ha.

Results based on islands surveyed a minimum of 4 years showed an average apparent annual increase of $21.6 \%$ for Nain, $13.4 \%$ for Hopedale, and $18.1 \%$ for all areas over the 6-year period from 1998 to 2003 (Table 4). These estimates varied slightly with the number of survey years (e.g., the value for all islands surveyed a minimum of 2 years was $17.5 \%$ compared to $18.1 \%$ for islands surveyed a minimum of 4 years [Table 4]).

\section{Discussion}

Due to logistics, not all islands were surveyed each year, and assessments based on archipelago 
Table 3. Average \pm SD number of nests per island by archipelago and yeara. Data collected on the Labrador coast 1998-2003.

\begin{tabular}{lcccccc}
\hline Archipelago & 1998 & 1999 & 2000 & 2001 & 2002 & 2003 \\
\hline Nain & $14.5 \pm 19.6$ & $17.6 \pm 23.9$ & $21.6 \pm 26.3$ & $32.4 \pm 24.1$ & $40.7 \pm 52.4$ & $46.3 \pm 51.9$ \\
Hopedale & $3.3 \pm 7.1$ & $4.3 \pm 7.8$ & $5.7 \pm 9.8$ & $4.8 \pm 7.7$ & $5.4 \pm 8.4$ & $10.7 \pm 20.4$ \\
Rigolet & & & $90.5 \pm 153.9$ & $144.9 \pm 195.9$ & $74.9 \pm 86.9$ & $141.3 \pm 167.1$ \\
St. Peter's Bay & $55.9 \pm 57.0$ & & $81.0 \pm 93.0$ & $42.9 \pm 51.1$ & \\
\hline
\end{tabular}

${ }^{a}$ Note that these average values do not take into account missing data (some islands were not searched every year) and are presented as general information.

level or year summaries tend to be misleading when plot or route data are missing. However the program ESTEQNINDEX allows for trend estimation with missing data (Collins 2003). Based on our analysis of average nest initiation dates, which ranged from a mean of 5 June in St. Peter's Bay to 23 June in Nain (Chaulk et al. 2004, Chaulk et al. 2005), we feel confident that our surveys were well timed to occur in mid to late incubation. On average about $71 \%$ of nests were classed as incubating, and only $10 \%$ were classed as hatched or hatching (Chaulk et al. 2005). Meanwhile, analysis of our sampling design suggests that within the subset of islands $<30$ ha, the sampling effort was not spatially biased (K.G. Chaulk, Labrador Inuit Association, unpublished data). We feel confident that nest detection rates were high due to the absence of obscuring ground cover.

Recent studies of northern common eider population trends have shown drastic disturbing patterns of population decline (Robertson and Gilchrist 1998, Suydam et al. 2000, Merkel 2004). In contrast, our results show positive population growth for eider populations in Labrador. The average levels of population increase that we have detected are very high (13-22\%). Given the geographic coverage of our surveys and the intensity of island searches that ranged from 2 to 4 archipelagos and 45-109 islands/year, we consider that our results are representative of common eider population trends in Labrador. From 1998 to 2003, average population growth in Nain was almost twice that of Hopedale. Reasons for these regional differences are unknown but could be related to local environmental conditions and/or harvesting practices. However, we lack data for both these factors and can make no substantiated assessment at this time.

In 1980, Lock (1986) conducted aerial surveys for breeding eiders and estimated 15,000 pairs on the Labrador coast. During the mid-1990s, the Canadian Wildlife Service conducted aerial surveys on the Labrador coast and estimated 30,000 breeding pairs of eiders and an annual growth rate of $3.7 \%$ per year during the intervening period (S. Gilliland, Canadian Wildlife Service, unpublished data). However, these 2 surveys were not directly comparable given the different methodologies employed, so both the status and trend of eider populations remained unclear through the 1980 s and 1990s. We are reluctant to use our data to generate population estimates, as our study was designed for trend estimation. Due to the limited quality of base maps, we have no way to determine what proportion of islands $<30$ ha is actually suitable for nesting eiders. Some islands might be submerged at high tide, connected to mainland at low tide, offer little shelter from ocean storms, or have cabins situated on them.

Table 4. Apparent annual change (\%) in breeding common eider populations on the Labrador coast 1998-2003. Due to limited samples sizes values for Rigolet and St. Peter's Bay were not presented individually (see footnote). These values are based on an analysis conducted using the program ESTEQNINDEX, which calculates population trend with missing data (Collins 2003).

\begin{tabular}{|c|c|c|c|c|c|}
\hline \multirow[b]{2}{*}{ Archipelago } & \multirow{2}{*}{$\begin{array}{l}\text { Minimum no. } \\
\text { of survey years }\end{array}$} & \multirow{2}{*}{$\begin{array}{c}\text { No. of islands } \\
\text { used in the model }\end{array}$} & \multirow{2}{*}{$\begin{array}{c}\text { Apparent annual } \\
\text { percentage change } \\
\text { in breeding population }\end{array}$} & \multicolumn{2}{|c|}{$95 \% \mathrm{Cl}$} \\
\hline & & & & Lower & Upper \\
\hline \multirow[t]{3}{*}{ Nain } & 4 & 21 & 21.6 & 1.6 & 35.8 \\
\hline & 3 & 26 & 21.6 & 6.1 & 39.5 \\
\hline & 2 & 36 & 22.4 & 7.5 & 39.2 \\
\hline \multirow[t]{3}{*}{ Hopedale } & 4 & 34 & 13.4 & 2.4 & 25.6 \\
\hline & 3 & 40 & 13.1 & 2.2 & 25.3 \\
\hline & 2 & 49 & 14.8 & 3.8 & 26.8 \\
\hline \multirow[t]{3}{*}{ All } & $4^{a}$ & 58 & 18.1 & 6.7 & 30.7 \\
\hline & $3^{b}$ & 79 & 17.5 & 6.7 & 29.4 \\
\hline & $2^{b}$ & 117 & 17.5 & 8.2 & 27.5 \\
\hline
\end{tabular}

a Includes Islands from Nain, Hopedale, and Rigolet.

b Includes islands from Nain, Hopedale, Rigolet, and St. Peter's Bay. 
Previously, we found that eider island occupancy ranged from 30 to $80 \%$ of islands surveyed, but these occupancy rates varied with archipelago (Chaulk et al. 2005). In the meantime, estimates of eider population size in Labrador will be unreliable until we can quantify the number of islands that are available and suitable for breeding.

Specific factors influencing eider population growth in Labrador could include improvement of environmental conditions or changes in migration patterns and subsequent changes in harvest on the breeding and wintering grounds. Other factors that may have influenced population growth include nest shelter programs, eider conservationeducation programs, and reductions in eider bag limits during the 1980s and 1990s. In addition, the commercial Atlantic salmon (Salmo salar) and cod (Gadus morhua) fisheries were closed in the early 1990s. Researchers have identified human disturbance as a key factor influencing eider distributions and reproductive performance (Blumton et al. 1988, Johnson and Krohn 2002). Closure of these fisheries could have improved conditions for breeding eiders by reducing human disturbance near colonies (Chaffey 2003), reducing hunting on the breeding grounds, and eliminating bycatch in nets as a mortality source. In addition, large gull populations in Labrador appear to be declining (Robertson et al. 2002) and may have further improved breeding conditions for eiders through a reduction in avian predation rates.

Based on this information, we think there are numerous reasons why breeding eider populations in Labrador are increasing. However, we are not certain why an adjacent population in southwestern Greenland is declining (Merkel 2004). It has been suggested that hunting is the main factor causing the decline in Greenland, where eiders are subjected to unsustainable harvest (Merkel 2004). Meanwhile, no recoveries of eiders banded in Labrador have been reported in Greenland (Lyngs 2003), suggesting little or no connection between the 2 populations. Researchers have suggested that Labrador eiders winter in Newfoundland, Quebec, and the Maritimes (Palmer 1976, Reed and Erskine 1986, Wendt and Silieff 1986, Goudie et al. 2000) and may experience lower harvest levels than eiders that winter in Greenland.

Typically, eiders have deferred sexual maturity and exhibit low rates of annual recruitment, and reproduction (Coulson 1984) and population growth is tied to adult survival (Goudie et al. 2000). However, eider populations can apparently sustain dramatic rates of increase, especially during population regrowth. Chapdelaine (1995) documented $11.3 \%$ and $23.5 \%$ annual growth for common eiders breeding in the Gulf of St. Lawrence. While a number of eider populations in the Netherlands grew at rates between 17-28\%, this occurred during the early stages of colony growth and was credited to low mortality and high rates of recruitment (Swennen 2002). Meanwhile, 25-35\% per year increases were observed at newly established Danish colonies due mainly to immigration (Bregnalle et al. 2002).

The extent that anthropogenic factors influenced overall eider population dynamics in Labrador in the 20th century is unknown, yet our evidence suggests significant population increases during the late 1990 s and early twenty-first century. These growth patterns are similar to those recently observed in Newfoundland (S. Gilliland, Canadian Wildlife Service, personal communication) and the Gulf of St. Lawrence (Chapedelaine 1995), and it is a promising trend for a species undergoing declines throughout much of its range.

Management Implications. - If general conditions remain constant, we feel that current eider harvest levels in Labrador are sustainable, at least in the short term. Given the baseline information that is now in place, we recommend continued population monitoring on a 3- to 4-year rotation. We also suggest expanding study scope to include unsurveyed portions of the Labrador coast. A rigorous assessment of suitable breeding islands is also suggested, and once complete, we recommend that regional population estimates be generated.

Acknowledgments.-Special thanks to P. Ryan (Canadian Wildlife Service); N. Anderson, E. Anderson, C. Bradley, K. Dicker, C. Dyson, C. Poole, D. Pottle, W. Wolfrey (Fisheries and Oceans Canada); and J. Rowell, B. Anderson, W. Hunter, E. Merkuratsuk, I. Winters, D. Wolfrey (Labrador Inuit Association). Thanks to S. Broomfield for help in preparing the data for analysis and to H. Chaffey for providing the 2002 nest count data for St. Peter's Bay. The Labrador Inuit Association, Canadian Wildlife Service, Northern Ecosystem Initiative, Northern Scientific Training Program, Memorial University of Newfoundland, and Voisey's Bay Nickel Company provided funding for this study. We appreciate the efforts of individuals who helped us in the field.

\section{Literature Cited}

Abraham, K. F., And G. H. Finney. 1986. Eiders of the eastern Canadian Arctic. Pages 55-73 in A. Reed, editor. Eider ducks in Canada. Canadian Wildlife Service Report Series, Number 47. 
Bregnalle, T., J. Gregersen, and P. U. Jepsen. 2002. Development of common eider Somateria mollissima colonies in the southwestern Kattegat, Denmark: influence of predators and immigration. Pages 15-24 in H. Noer and G. Nehls, editors. Population processes in the common eider Somateria mollissima. Danish Review of Game Biology Volume 16.

Blumton, A. K., R. B. Owen, And W. B. Krohn. 1998. Habitat suitability index models: American eider (breeding). U.S. Fish and Wildlife Service Biological Report 82(10.149).

CHAFFEY, H. 2003. Integrating science and local ecological knowledge (LEK): population history, exploitation and conservation in studies of eiders in southern Labrador. Thesis, Memorial University of Newfoundland, St. John's, Newfoundland and Labrador, Canada.

Chapdelaine, G. 1995. Fourteenth census of seabird populations in the sanctuaries of the North Shore of the Gulf of St. Lawrence, 1993. Canadian Field-Naturalist 109:220-226.

Chaulk., K. G., G. J. Robertson, and W. A. Montevecchi. 2004. Regional and annual variability in common eider nesting ecology in Labrador. Polar Research:in press.

$-, \longrightarrow,-$, AND P. RYAN. 2005. Aspects of common eider breeding ecology in Labrador. Arctic: in press.

Collins, B.T. 2003. ESTEQNINDEX: A program to analyse trend data: user guide and documentation. National Wildlife Research Center. Canadian Wildlife Service. Environment Canada, Ottawa, Canada.

Coulson, J.C. 1984. The population dynamics of the eider duck Somateria mollissima and evidence of extensive non-breeding by adult birds. Ibis 126:525-543.

Falardeau, G., J-F. Rail, S. Gilliland, and J.-P. L. SAVARD. 2003. Breeding survey of common eiders along the west coast of Ungava Bay, in summer 2000, and a supplement on other nesting aquatic birds. Canadian Wildlife Service, Québec Region, SainteFoy. Technical Report Series, Number 405.

Gratto-Trevor, C., V. H. JohnSton, and S. T. Pepper. 1998. Changes in shorebird and eider abundance in the Rasumssen Lowlands, NWT. Wilson Bulletin 110:31 6-325.

Goudie, R. I., G. J., Robertson, ANd A. ReEd. 2000. Common eider (Somateria mollissima). Number 546 in A. Poole and F. Gill, editors. The birds of North America. The Academy of Natural Sciences, Philadelphia, Pennsylvania, USA, and The American Ornithologists' Union, Washington, D.C., USA.

HipfNer, J. M., H. G. Gillchrist, A. J. Gaston, AND D. K. CAIRNS. 2002. Status of common eiders, Somateria mollissima, nesting in the Digges Sound region, Nunavut. Canadian Field-Naturalist 116:22-25.

Johnson, C. M., AND W. B. Krohn. 2002. Dynamic patterns of association between environmental factors and island use by breeding seabirds. Pages 171-181 in J. M Scott, P. J. Heglund, M. L. Morrison, J. B. Haufler, M. G. Raphael, W. A. Wall, and F. B. Samson, editors. Predicting species occurrences: issues of accuracy and scale. Island Press, Covelo, California, USA.

KERTELL, K. 1991. Disappearance of the Steller's eider from the Yukon-Kuskokwim Delta, Alaska. Arctic 44:1 77-187.

Lock, A. R. 1986. A census of common eiders breeding in Labrador and the Maritime provinces. Pages 30-38 in A. Reed, editor. Eider ducks in Canada. Canadian Wildlife Service Report Series, Number 47.

Lopoukhine, N., N. A. Prout, and H. E. Hirvonen. 1978. The ecological land classification of Labrador; a reconnaissance. Ecological Land Classification Series 4, Lands Directorate, Environmental Management Service, Fisheries Environment Canada, Halifax, Nova Scotia, Canada.

LyNGS, P. 2003. Migration and winter ranges of birds in Greenland: an analysis of ring recoveries. Dansk Ornitholigisk Forenings Tidsskrift 97.

MEADES, S. 1990. Natural regions of Newfoundland and Labrador. Report prepared for the Protected Areas Association of Newfoundland and Labrador. St. John's, Newfoundland and Labrador, Canada.

MENDALl, H. L. 1980. Intergradation of eastern North American common eiders. Canadian Field-Naturalist 94:286-292.

- 1986. Identification of eastern races of common eider. Pages 82-88 in A. Reed, editor. Eider ducks in Canada. Canadian Wildlife Service Occasional Report Series, Number 47.

MERKel, F. R., A. MOSBECH, D. BoERTMANN, AND L. GRøNDAL. 2002. Winter seabird distribution and abundance off south-western Greenland, 1999. Polar Research 21 :17-36. 2004. Evidence of population decline in common eiders breeding in western Greenland. Arctic 57:27-36.

NeTtLESHIP, D.N. 1976. Census techniques for seabirds of arctic and eastern Canada. Canadian Wildlife Service Occasional Paper Number 25.

— AND P.G.H Evans. 1985. Distribution and status of Atlantic alcidae. Pages 53-154 in D. N. Nettleship and T. R. Birkhead, editors. The Atlantic Alcidae. Academic Press, London, United Kingdom.

Palmer, R. S. 1976. Handbook of North American birds. Volume 3. Yale University Press, New Haven, Connecticut, USA

ReED, A., AND A. J. ERSKIne. 1986. Populations of common eider in eastern North America: their size and status. Pages 156-175 in A. Reed, editor. Eider ducks in Canada. Canadian Wildlife Service Report Series, Number 47.

Robertson, G. J., AND H. G. GILCHRIST. 1998. Evidence of population declines among common eiders breeding in the Belcher Islands, Northwest Territories. Arctic $51: 378-385$.

—, R. D. Elliott, And K. G. Chaulk. 2002. Breeding seabird populations in Groswater Bay, Labrador, 1978 and 2002. Canadian Wildlife Service Technical Report Series, Number 394.

SOKAL, R. R., AND F. J. RoHLF. 1995. Biometry: the principles and practice of statistics in biological research. Third edition. W. H. Freeman, San Francisco, California, USA.

Stehn, R. A., C. P. Dau, B. Conant, and W. I. Butler, JR. 1993. Decline of spectacled eider nesting in western Alaska. Arctic 46:264-277.

Suydam, R. S., D. L. Dickson, J. B. Fadley, And L. T. QuaKENBUSH. 2000. Population declines of king and common eiders of the Beaufort Sea. Condor 102:21 9-222.

Swennen, C. 2002. Development and population dynamics of common eider Somateria mollissima colonies in the Netherlands. Pages 63-74 in H. Noer and G. Nehls, editors. Population processes in the common eider Somateria mollissima. Danish Review of Game Biology Volume 16.

WENDT, J. S., AND E. SiLIEFF. 1986. The kill of eiders and other sea ducks by hunters in eastern Canada. Pages 147-154 in A. Reed, editor. Eider ducks in Canada. Canadian Wildlife Service Report Series, Number 47.

Associate Editor: Green. 